\title{
蝶形骨泀と錐体尖蜂巣の関連について
}

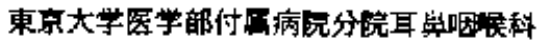

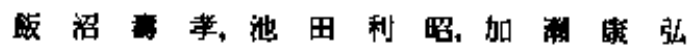 \\ 栗 占純 - , 市村意一, 山报雅昭
}

\section{ANATOMICAL STUDY ON THE SPHENOIDAL SINUS AND THE PETROUS APEX CELLS}

TOSHITAKA IINUMA, M.D., TOSHIAKI LKEDA, M.D., YASUHIRO KASE, M.D. JUN-ICHI KURIYAMA, M.D., KEJCHI JCHIMURA, M.D. and MASAAKI YAMANE, M.D.

\section{Department of Otolaryngology, Tokyo University Branch Hospital, Bunkyo-ku, Tokyo}

Morphological relation between the sphenoidal sinus and the petrous apex cell was studied using HRCT images obtained by 399 adults and 43 infants. The adults were classified into normal group (without chronic otitis media or its surgery) 237 cases, and otitis group (chronic otitis media or its post. op.), 102 cases. The posterior extent of the sphenoidal sinus was evaluated in reference to the carotid canal, and the petrous apex cells were evaluated by their mode of distribution in the apex.

In the normal aduits, no evident relation was seen between the posterior extent and the mode of distribution. Although adukt normal female showed statistically significant better development of the posterior extent, sinus-cell reiation was similar between both sexes. The adult normal group and otitis group behave similarly by sinus-cell relation. i.e.. no evident relation, although inhibited mode of distribution was seen by otitis group. When the adult and infant were compared. the sinus-cell relation was simitar and the posterior extent suffered underdevelopment by infant.

The distance, between the posterior extension of the sphenoidal sinus and the apex cell at the medial-anterior tip of the petrous bone, is between $8-16 \mathrm{~mm}$ and the contact of the both separated by thin bony wall (tess than $0.5 \mathrm{~mm}$ ) was seen in 3 adult cases $(0.9 \%$ ).

Both the sphenoidal sinus and the petrous apex cells are under genetic influence of variable degree, separate genes seem to be at work, thus effecting no evident relation between the two. Apart from the internal or genetic influence, environmental or outer influence also affects the development of the two, less than the genetic. And the common factor as the inflammation might bring about adverse effects upon the development of the two, as both the sinus and cells often suffer common underdevelopments.

The trans-sphenoidal approach to the petrous apex is indicated when the apex is already expanded and in contact with the sinus wall. Rare cystic lesions and primary cholesteatoma are reported as operated upon by this approach. 
始めに

蝶形骨洞と錐体尖蜂巣とは共に中頭蓋窩底に存在す る含気腔であるが，両者の発育が良好であると時とし て錐体尖において互いに接することがある。副鼻腔と 中耳腔 (蜂巣) との発育程度の関連については従来か ら少なからず報告があるが, 関連の有無については結 論に一致を見ない. また, 従来の比較検討は主として 前頭洞並びに上顎洞と乳突蜂巣との発育に関するもの で，蝶形骨洞と錐体尖蜂巣に関する比較検討はなされ ていない.

今回の報告は蝶形骨洞と錐体尖蜂巣との関連を検討 したものであるが, 発育の関係に加えて, 互いに発育 が良好な場合における相互の解剖関係を検討したもの である。

なお，錐体尖蜂巣に関する定義には諸説があるが， Tobeck $^{11}$ は内耳骨包周囲および内耳骨包より内方の 蜂巣とし, Schmidt ${ }^{2)}$ はStenvers 法で前半規管より内 方とした。黒須 ${ }^{3)}$ は同様に内耳骨包より内方とし，末 廣4)はStenvers 法で蝸牛殼より先端とした。最近の定

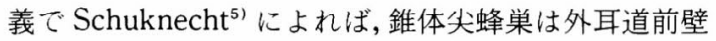
と蝸牛軸を通過する面より内方のものとする．今回の 報告では黒須ならびに末廣の定義に準じて, 蝸牛殼よ り内方の部分を錐体尖とし,この部位の蜂巣を錐体尖 蜂巣とする。

\section{I 対象ならびに方法}

対象は何らかの耳疾患で高分解能 CTを施行した成 人 339 症例と小児 43 症例である. 耳疾患には難聴, 眩莗 などを主訴とした内耳疾患, 後迷路性疾患またはその 疑い, 慢性中耳炎（真珠腫をふくむ）とその術後をふ くむ. 以下では慢性中耳炎とその術後を中耳炎群とし, そ机以外のものを正常群（非炎症性）とした。なおこ れらの症例の副鼻腔は正常か軽度病変をのみ示し, 中 等度以上の病変は除外した。成人症例の内訳は正常群 237 症例，中耳炎群102症例，小览症例では正常群26症 例, 中耳炎群17症例である。性別では成人で男子 142 , 女子197, 小児で男子21, 女子22である.なお小児は16 歳以内とした。年齢分布を表 1 に示す.

蝶形骨洞ならびに錐体尖蜂巣の分析には高分解能 CT 画像を用いた。画像は東芝 TCT $60 \mathrm{~A} / 60$ により, 側 頭骨用高分解能プログラムを用い，スライス幅 $2 \mathrm{~mm}$, $1 \mathrm{~mm}$ オーバーラップとして, ウインドウレベル70100，ウインドウ幅14000スカウトビューである. 分析に用いた軸位形面は 2 面であり, 第 1 面は底面
表 1 年齢分布

\begin{tabular}{|c|c|c|}
\hline & 男 & 女 \\
\hline 成人, 正 常 & $47.1(14.3)$ & $47.8(14.0)$ \\
\hline 成人, 中耳炎 & $46.1(12.0)$ & $50.4(13.0)$ \\
\hline 小 & \multicolumn{2}{|c|}{$10.0(4.36)$} \\
\hline
\end{tabular}

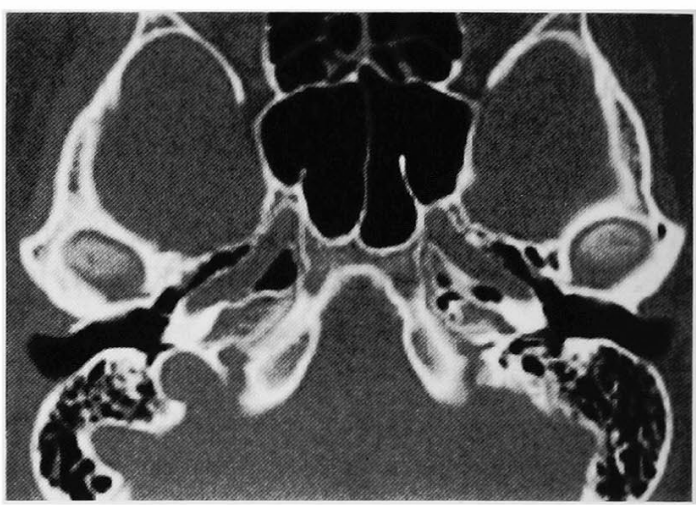

図 1 第 1 面，底面

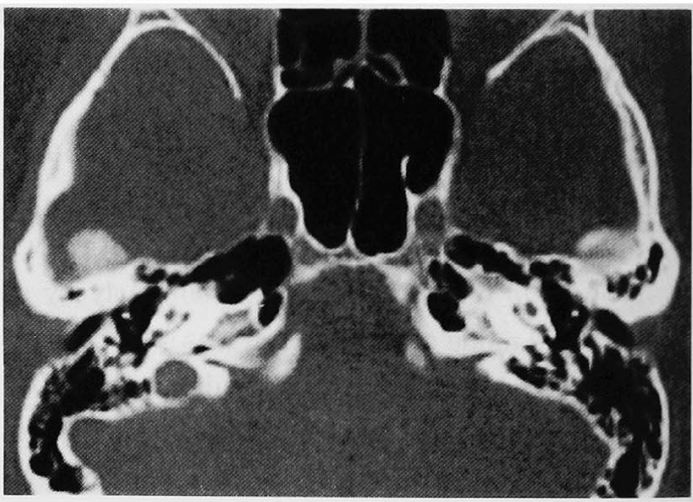

図 2 第 2 面, 上面

で，内頸動脈管部と蝸牛基底回転を含む面とし，第 2 面はその 2 断面上方の上面で, 内頸動脈管部の直上て 蝸牛軸を通過する面である（図 1 および図 2 ).

蝶形骨洞後方進展の分類は図 3 のごとくに, 内頸動 脈管部または内頸動脈に達せず前方にとどまるものを I , 接するものを II, 内頸動脈の直径の $1 / 2$ に達するも のをIII, 直径を越えてさらに後方に進展するものをIV, とした，錐体尖蜂巣の分類は図 4 のごとくに，底面で は内頸動脈管部を基準として,その1/2宛に前後して分 割して, 内頸動脈管部より内方にあるものを，そ㧈ぞ れ 1 および 2 とし, 外側にあるものを 3 および 4 とし た。また，上面では内頸動脈の内側で錐体尖部を内外 


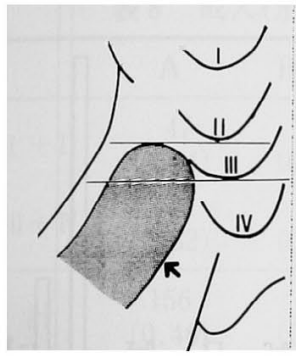

(1)

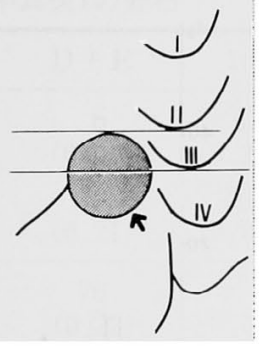

(2)

図３蝶形骨洞後方進展の分類

(1) 底面，(2) 上面 矢印は内頸動脈管

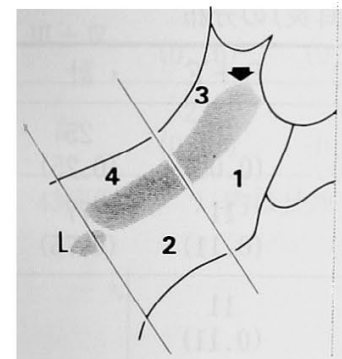

(1)

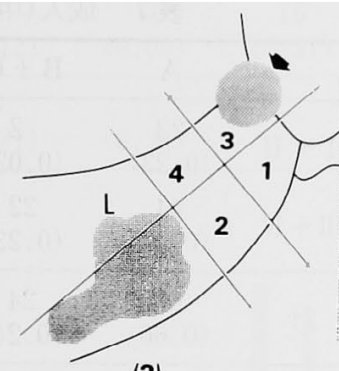

(2)

図4錐体尖蜂巣の分類

（1）底面，(2) 上面

矢印は内頸動脈管, L は内耳骨包

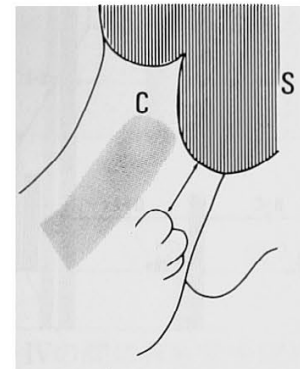

(1)

図 5 蝶形骨洞と錐体尖蜂巣の距離

(1) 底面, (2) 上面

$\mathrm{S}$ : 蝶形骨洞, C：内頸動脈管

に分割し，さらにこれを前後に等分割して，1，2， 3,4 とした.

蝶形骨洞の後方進展部位と錐体尖蜂巣のうちで，底 面および上面において 1 に存在するものとの最短距離 を計測した(図 5 )。
表 2 錐体尖蜂巣分布の分類

\begin{tabular}{lll}
\hline $\mathrm{A}$ & $0-0$ & 両側に蜂巣なし \\
$\mathrm{B}$ & $4-0$ & 片側にのみ蜂巣 $(4)$ あり \\
$\mathrm{C}$ & $4-4$ & 両側に蜂巣 $(4)$ あり \\
$\mathrm{D}$ & $3-0$ & 片側にのみ蜂巣 ( 3 以下)あり \\
$\mathrm{E}$ & $3-4$ & 片側に蜂巣 ( 3 以下) \\
& & 対側に蜂巣 ( 4 以下)あり \\
\hline
\end{tabular}

表 3 成人 (正常)の分布

\begin{tabular}{|c|c|c|c|c|c|c|c|}
\hline & \multicolumn{7}{|c|}{ 錐体尖蜂巣蜂巣の発育と分布 } \\
\hline & & A & $\mathrm{B}$ & $\mathrm{C}$ & $\mathrm{D}$ & $\mathrm{E}$ & 計 \\
\hline \multirow{5}{*}{ 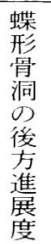 } & I & 15 & 2 & 1 & 1 & 4 & 23 \\
\hline & II & 9 & 6 & 3 & 1 & 0 & 19 \\
\hline & III & 13 & 4 & 1 & 1 & 6 & 25 \\
\hline & IV & 52 & 24 & 42 & 11 & 41 & 170 \\
\hline & 計 & 89 & 36 & 47 & 14 & 51 & \\
\hline
\end{tabular}

表 4 成人(正常)の分布

\begin{tabular}{ccccc}
\hline & $\mathrm{A}$ & $\mathrm{B}+\mathrm{C}$ & $\mathrm{D}+\mathrm{E}$ & 計 \\
\hline I + II & 24 & 12 & 6 & 42 \\
& $(0.10)$ & $(0.05)$ & $(0.03)$ & $(0.18)$ \\
III + V & 65 & 71 & 59 & 195 \\
& $(0.27)$ & $(0.30)$ & $(0.25)$ & $(0.82)$ \\
\hline 計 & 89 & 83 & 65 & \\
& $(0.38)$ & $(0.35)$ & $(0.27)$ & \\
\hline
\end{tabular}

$\mathrm{I}+\mathrm{II}, \mathrm{III}+\mathrm{IV}$ は蝶形骨洞後方進展度, $\mathrm{A}, \mathrm{B}+\mathrm{C}$, $\mathrm{D}+\mathrm{E}$ は錐体尖蜂巣の発育と分布様式 (本文参照) 237症例，（）内は比率

なお，蝶形骨洞の後方進展および錐体尖蜂巣の分析 は各症例において左右を別個に, 底面と上面において 行ったが, 蝶形骨洞は正中の構造であり, 左右の大き さに不均等があって, 例えば左蝶形骨洞の後方進展が 右の錐体尖蜂巣に接することもまれではない.そのた め, 左右，および底面と上面とで分析した結果を症例 毎に総合して,錐体尖蜂巣の分類を表 2 のごとくとし， $1,2 ， 3 ， 4$ の組み合わせのうちで, 最も分類番号 の小であるものをその症例の観察結果とした．検定は $\chi$ 二乗検定および Fischer 直接確率に拠つた。

\section{II 結 果}

1. 成人 (正常) の分布

表 3 は成人, 正常群における, 蝶形骨洞の後方進展, 


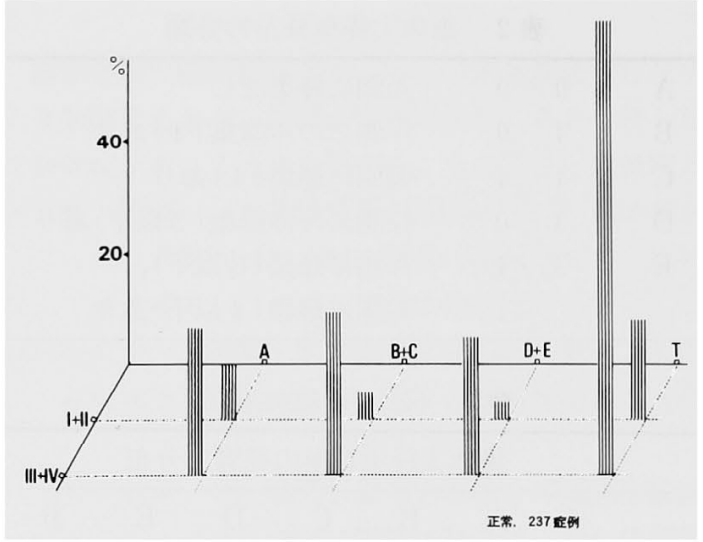

図 6 成人正常群

I + II, III + IV は蝶形骨洞後方進展度, A, $\mathrm{B}+\mathrm{C}, \mathrm{D}+\mathrm{E}$ は錐体尖蜂巣の発育と分布様 式（本文参照）

表 5 男子(正常)の分布

\begin{tabular}{ccccc}
\hline & $\mathrm{A}$ & $\mathrm{B}+\mathrm{C}$ & $\mathrm{D}+\mathrm{E}$ & 計 \\
\hline $\mathrm{I}+\mathrm{II}$ & 11 & 8 & 5 & 24 \\
& $(0.11)$ & $(0.08)$ & $(0.05)$ & $(0.25)$ \\
$\mathrm{III}+\mathrm{IV}$ & 26 & 23 & 23 & 72 \\
& $(0.27)$ & $(0.24)$ & $(0.24)$ & $(0.75)$ \\
\hline 計 & 37 & 31 & 28 & \\
& $(0.39)$ & $(0.32)$ & $(0.29)$ & \\
\hline
\end{tabular}

96症例，（）内は比率

表 6 女子(正常)の分布

\begin{tabular}{ccccc}
\hline & $\mathrm{A}$ & $\mathrm{B}+\mathrm{C}$ & $\mathrm{D}+\mathrm{E}$ & 計 \\
\hline I + II & 13 & 4 & 1 & 18 \\
& $(0.09)$ & $(0.03)$ & $(0.007)$ & $(0.13)$ \\
$\mathrm{III}+\mathrm{IV}$ & 39 & 48 & 36 & 123 \\
& $(0.28)$ & $(0.34)$ & $(0.26)$ & $(0.87)$ \\
\hline \multirow{2}{*}{ 計 } & 52 & 52 & 37 & \\
\hline
\end{tabular}

141症例，（）内は比率

I, II, III, IV, と錐体尖蜂巣の分類 (表 2), A, B, $\mathrm{C}, \mathrm{D}, \mathrm{E}$ の関連を示す 以下の分析では I + II, III+ $\mathrm{IV}$, の組分けと $\mathrm{A}, \mathrm{B}+\mathrm{C}, \mathrm{D}+\mathrm{E}$, の組分けにまとめて 行う. 統計的検定の便宜のためである.

表 4 はその結果である. I + II は蝶形骨洞の後方進 展が不良，III+IVは良好であることを示す，A，B+C， $\mathrm{D}+\mathrm{E}$ ，はそれぞれ錐体尖蜂巣の発育が，不良，やや良 好，良好，であることを示す。これを図示すれば，図

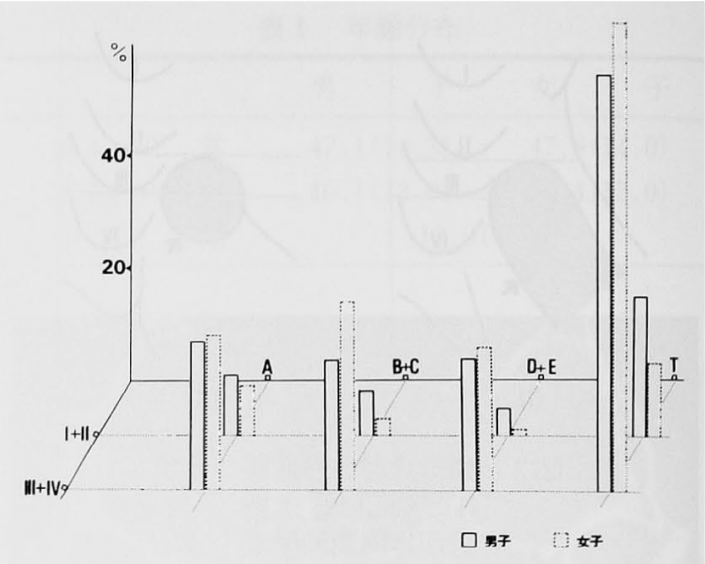

図 7 成人正常群, 男女の比較

表 7 成人(中耳炎)の分布

\begin{tabular}{ccccc}
\hline & $\mathrm{A}$ & $\mathrm{B}+\mathrm{C}$ & $\mathrm{D}+\mathrm{E}$ & 計 \\
\hline \multirow{2}{*}{ I + II } & 23 & 2 & 0 & 25 \\
& $(0.23)$ & $(0.02)$ & $(0.00)$ & $(0.25)$ \\
III + IV & 44 & 22 & 11 & 77 \\
& $(0.43)$ & $(0.23)$ & $(0.11)$ & $(0.75)$ \\
\hline 計 & 67 & 24 & 11 & \\
\hline
\end{tabular}

102症例，（）内は比率

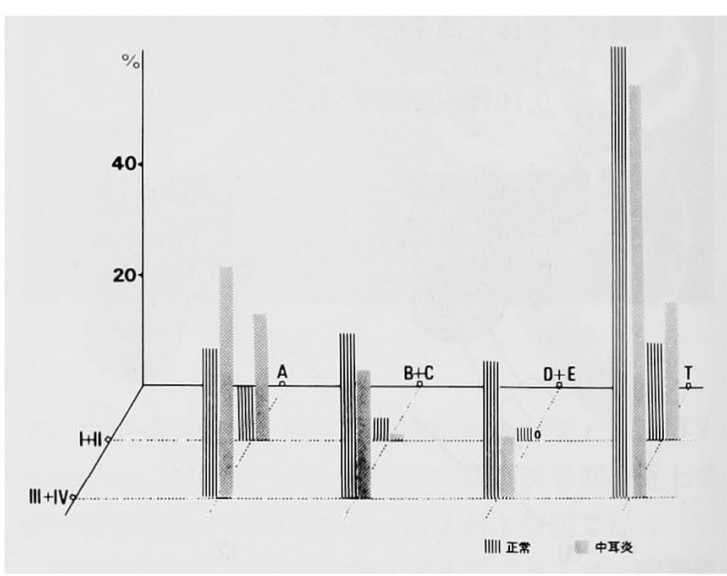

図 8 正常群と中耳炎群の比較

6 となる. 成人, 正常群において, 蝶形骨洞の後方進 展が良好である場合では, 錐体尖蜂巣の発育程度によ る分布はほぼ均等であるが, 後方進展が不良であると, 錐体尖蜂巣発育不良例が多い.

2. 成人（正常）の男女別分布

表 5 と 6 とはそれぞれ男子および女子の分布を示 し, 図 7 にそれらを図示する。これらの分布で I + II, 
表 8 成人 (正常, 中耳炎)の分布

\begin{tabular}{ccccc}
\hline & $\mathrm{A}$ & $\mathrm{B}+\mathrm{C}$ & $\mathrm{D}+\mathrm{E}$ & 計 \\
\hline I + II & 47 & 14 & 6 & 67 \\
& $(0.14)$ & $(0.04)$ & $(0.02)$ & $(0.20)$ \\
III + IV & 109 & 93 & 70 & 272 \\
& $(0.32)$ & $(0.27)$ & $(0.21)$ & $(0.80)$ \\
\hline 計 & 156 & 107 & 76 & \\
\hline
\end{tabular}

339症例，（）内は比率

表 9 小児(正常, 中耳炎)の分布

\begin{tabular}{ccccc}
\hline & $\mathrm{A}$ & $\mathrm{B}+\mathrm{C}$ & $\mathrm{D}+\mathrm{E}$ & 計 \\
\hline $\mathrm{I}+\mathrm{II}$ & 16 & 4 & 7 & 27 \\
& $(0.37)$ & $(0.09)$ & $(0.16)$ & $(0.63)$ \\
$\mathrm{III}+\mathrm{IV}$ & 7 & 5 & 4 & 16 \\
& $(0.16)$ & $(0.12)$ & $(0.09)$ & $(0.37)$ \\
\hline 計 & 23 & 9 & 11 & \\
\hline
\end{tabular}

43症例, （）内は比率

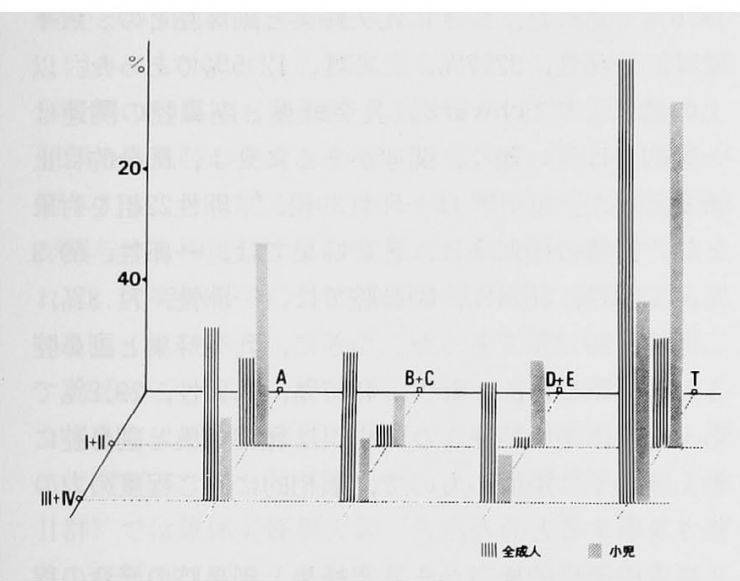

図 9 成人と小児の比較

$\mathrm{III}+\mathrm{IV}$ の間に有意差を認める部位は $\mathrm{B}+\mathrm{C}, \mathrm{D}+\mathrm{E} ， お$ よび T（横の合計）である。すなわち，女子ではIII+ IVで B $+\mathrm{C}, \mathrm{D}+\mathrm{E} ，$ の占める率が男子より高く，全体 として，III+IVの占める率も高い.

3. 成人 (中耳炎) の分布

表 7 は成人 (中耳炎) の分布を示し, 図 8 は成人の 正常群と中耳炎群とを比較するものである。これらの 間にはいずれの部位でも有意差を認めない。

4. 成人と小児の比較

成人（正常群，中耳炎群）扔よび小览（正常群，中
表10 錐体尖蜂巣の出現率

\begin{tabular}{cccc}
\hline & $\mathrm{A}$ & $\mathrm{B}+\mathrm{C}$ & $\mathrm{D}+\mathrm{E}$ \\
\hline 男子(142症例) & 70 & 40 & 32 \\
& $(0.49)$ & $(0.28)$ & $(0.23)$ \\
女子(197症例) & 86 & 67 & 44 \\
& $(0.44)$ & $(0.34)$ & $(0.22)$ \\
成人 (339症例) & 156 & 107 & 76 \\
& $(0.46)$ & $(0.32)$ & $(0.22)$ \\
小児 (43症例) & 23 & 9 & 11 \\
& $(0.53)$ & $(0.21)$ & $(0.26)$
\end{tabular}

$\mathrm{A}$ ：錐体尖蜂巣，欠如， B + C : 同，やや発育良 好, $\mathrm{D}+\mathrm{E}$ : 同, 発育良好 (本文参照) 症例数, （）内は比率

表11 蝶形骨洞と錐体尖蜂巣の距離

\begin{tabular}{llrrr}
\hline & & 底 部 & \multicolumn{1}{c}{ 上 部 } \\
\hline \multirow{2}{*}{ 成人, 正 常 } & & 男子 & $16.0(7.3)$ & $13.9(8.1)$ \\
& & 女子 & $12.5(7.3)$ & $8.4(4.9)$ \\
\multirow{2}{*}{ 成人, 中耳炎 } & 男子 & $8.7(2.6)$ & $8.4(4.9)$ \\
\multirow{2}{*}{ 小 } & 女子 & $14.2(9.0)$ & $8.1(5.2)$ \\
& & & $16.5(7.3)$ & $9.6(7.8)$ \\
\hline
\end{tabular}

単位 mm,（）内, 標準偏差

耳炎群）の分布。それぞれ表 8 と 9 に示す。また，表 8 と 9 をまとめて図 9 に示す I + II，III+IV，の間 には $\mathrm{A}, \mathrm{B}+\mathrm{C}, \mathrm{D}+\mathrm{E}, \mathrm{T}$ (横の合計)のいずれにおい ても有意差を認める。すなわち，小児において蝶形骨 洞の後方進展は錐体尖蜂巣の発育の如何によらず不良 である。

\section{5. 蝶形骨洞と錐体尖蜂巣の距離}

はじめに錐体尖蜂巣の出現率を表10に示すこれら の間にはいずれの組み合わせにおいても，有意差はな い.これらのうちで, Eに蜂巣が存在した症例数は成人 59 症例, 小児 7 症例である. $\mathrm{E}$ から蝶形骨洞後方進展部 位までの距離（生体での実測值に換算）を表11に示す。 なお互いが $0.5 \mathrm{~mm}$ 以内の菲薄な隔壁で接する形態は 成人，男子の 3 症例にみられた。

6. 結果のまとめ

蝶形骨洞の発育の指標として後方進展を用い, 錐体 尖蜂巣の発育の指標に錐体尖の蜂巣の分布状態を用い た.後方進展が不良か良好かを基準にして検討すると， 良好な場合での錐体尖蜂巣の分布は蜂巣の発育状態に 無関係である，ただし，不良な場合では，錐体尖蜂巣 の発育も不良である傾向がある，男女成人を比較する と，女子において後方進展が良好例において有意に錐 


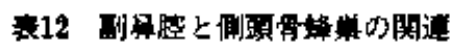

\begin{tabular}{|c|c|c|c|c|c|c|}
\hline 蚱告者 & 垶告年 & 詨 象 & 方 法 & 䦗育数 & 比较対告 & 純 \\
\hline Turner ${ }^{6}$ & 1922 & 摽 本 & $\mathrm{X}$ 楾 & 578 & 拜突一前 & 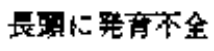 \\
\hline Beck" & 1927 & 生 体 & $\mathrm{X}$ 線 & 不 明 & 乳突一副 & あち程庭閉遇 \\
\hline Talpis ${ }^{g \prime}$ & 1928 & 頭重骨 & $\mathrm{X}$ & 93 & $\begin{array}{l}\text { 乳突一前 } \\
\text { 乳突一副 }\end{array}$ & 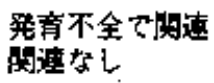 \\
\hline Schwarz & 1929 & 生体 & $\mathrm{X}$ & $\begin{array}{l}\text { 一卵， } 59 \\
\text { 二率，35 }\end{array}$ & $\begin{array}{r}\text { 乳突一前 } \\
\text {-上 } \\
\text { 一籍 }\end{array}$ & $\begin{array}{l}\text { 部分的に得理 } \\
\text { 同 上 } \\
\text { 同 上 }\end{array}$ \\
\hline Theissing ${ }^{10 r}$ & 1930 & 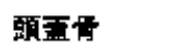 & $\mathrm{X}$ 的 & 150 & 乳突一前 & 厍遗なし \\
\hline 薜 田 & 1937 & 生 体 & $\mathrm{X}$ 線 & 400 㥸 & 乳突一前 & 相当な倩坴 \\
\hline 末 店" & 1943 & 标本, 生体 & $\mathrm{X}$ & $\begin{array}{l}282 \text { 測 } \\
261 \text { 偩 }\end{array}$ & $\begin{array}{l}\text { 鏙体一前 } \\
\text { 錐体一上 }\end{array}$ & $\begin{array}{l}\text { 一定度の的遇 } \\
\text { 関要なし }\end{array}$ \\
\hline 小 川|12r & 1960 & $\begin{array}{l}\text { 告体 } \\
\text { 双生児 }\end{array}$ & $\mathrm{X}$ & $\begin{array}{l}\text { 一卵, } 39 \\
\text { 二唧, } 22\end{array}$ & 秃突一副 & 进伝子流別 \\
\hline
\end{tabular}

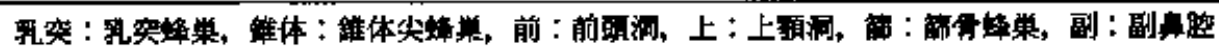

体尖䗋鼻の発市が良好な例加多い，正常例(非中耳炎

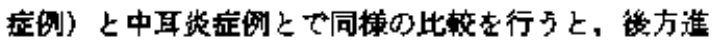

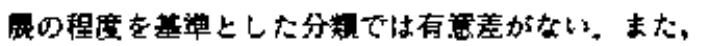
成人と小览とを比交すると、小児においで錐体尖峰整 の発育の如何によらす媒形贯洞の後方進共が不良です

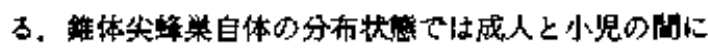
羑校的。

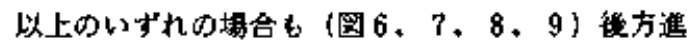

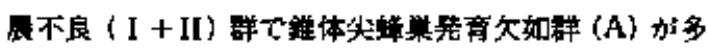
く分布しだ.

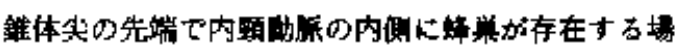

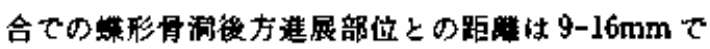

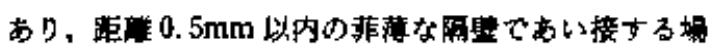
合は成人で 3 症国のみにみた。

\section{III 㮩}

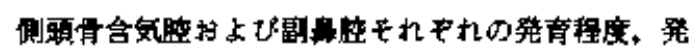
亦形式については従来から数多くの咞究と䡮告があ

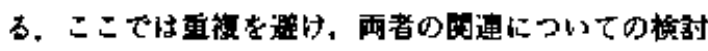
を主としたい。

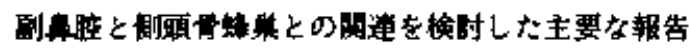

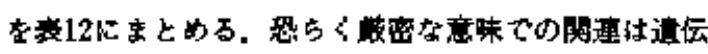
的研究によるべきであるうから，妒じに双生児を対

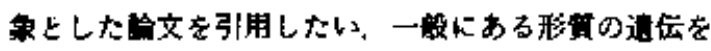

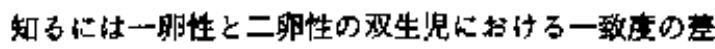

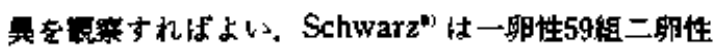

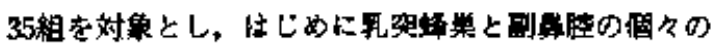

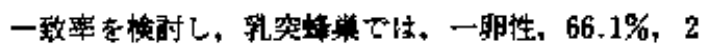

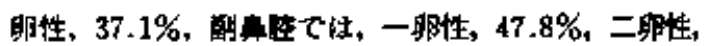

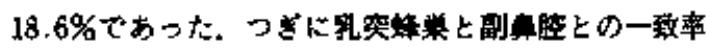
ては，一卵性，32.7\%，二䀧性，12.5\%でおった，以

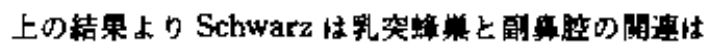

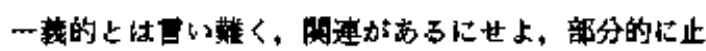

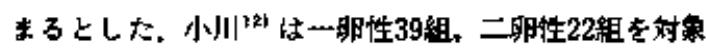

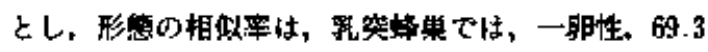

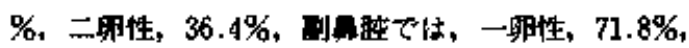

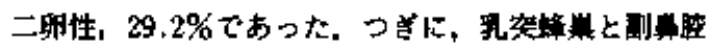

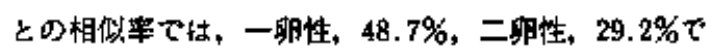

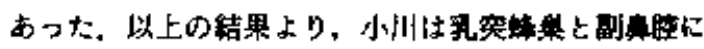

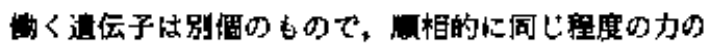
娈ざ有するとした。

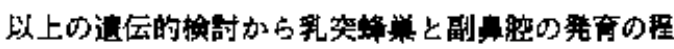

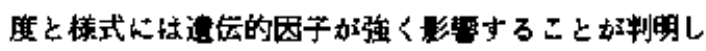

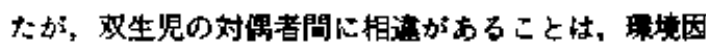
子も网与することを示す。

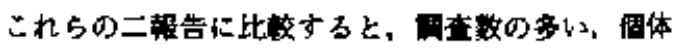
を祄象とした他の報告は周接的な正明に止まるのて，

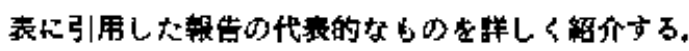

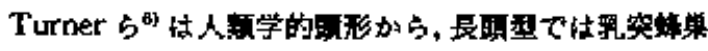

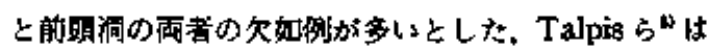

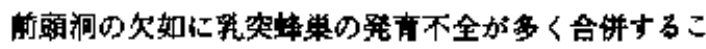

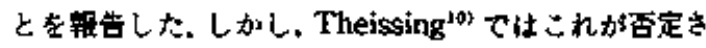
机。

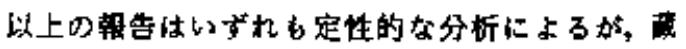




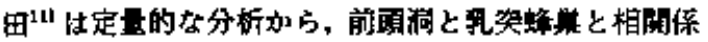
慗は0.382てかり，相当な闻连がありとした。

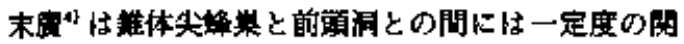

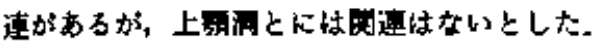

ここでわれわれの結果を分析してみたい，末ず基本

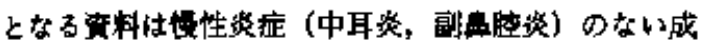

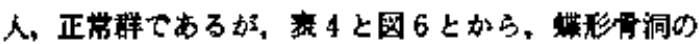

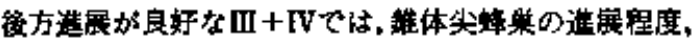
古わち、,

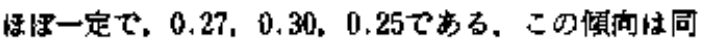
群を男女に分虬して (图 7) 梌时しても同棣て，女子

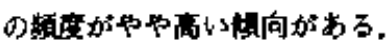

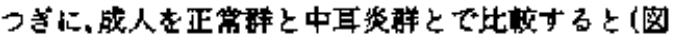
8). I + II, [II $+\mathrm{IV}, \cos \mathrm{A}, \mathrm{B}+\mathrm{C}, \mathrm{D}+\mathrm{E}$, क 场度

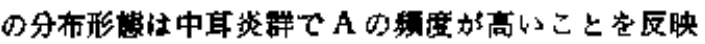
するのみてるる。

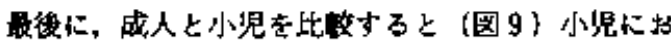
いで+IIの頌度が多いことを反映するのみでする。

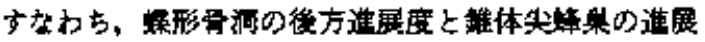

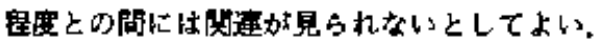

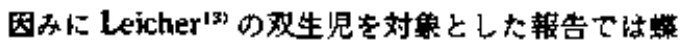

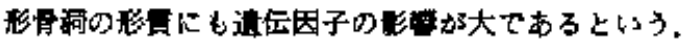

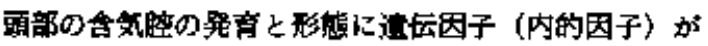

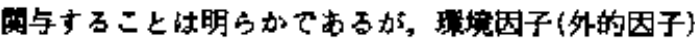

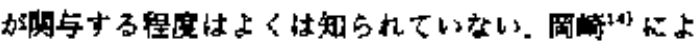

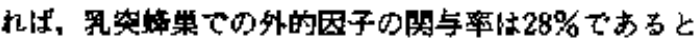
(3).

前述のごとくに，媒形㝵洞の役方進展度を基望とし

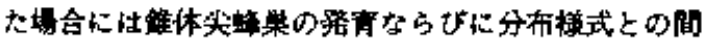
には関連がないとして上いが，盀方進展度不良（1+

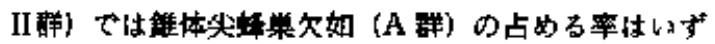
れの分析例（图 6，7，8，9）でも維体尖䗋学存在

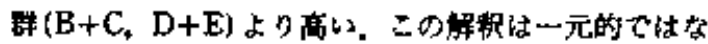

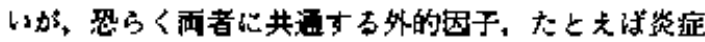

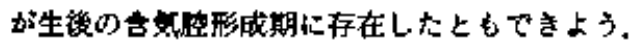

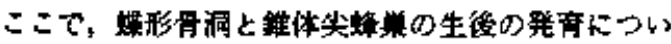

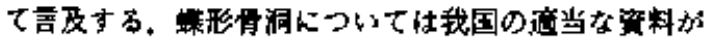

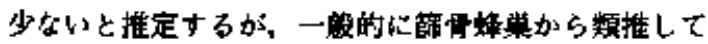

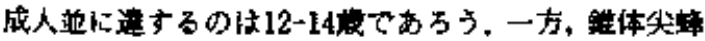

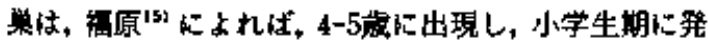

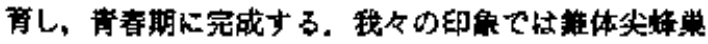
の完成は婐形骨洞に先行するようでる。

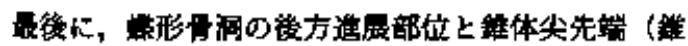

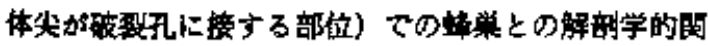

保を模討する。

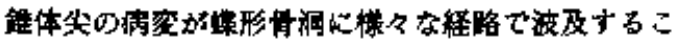

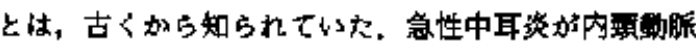

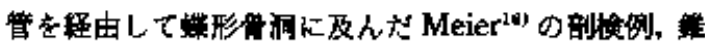

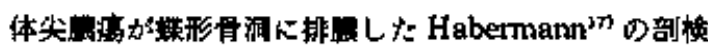
例方ある。

このように互いが近接する解剖阅倸を考心して，䧴

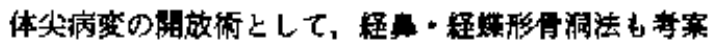

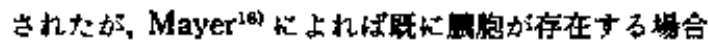

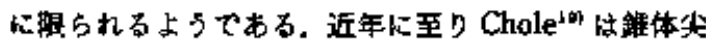

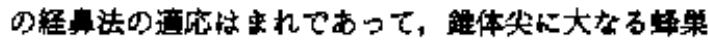

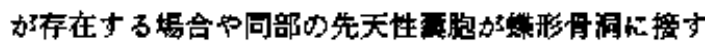
る场合に䧗るとした。こ机より先，Cole ${ }^{201}$ は雓体尖に

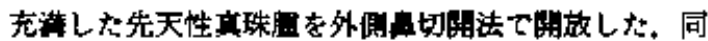

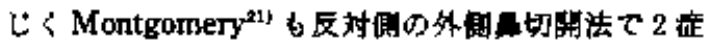

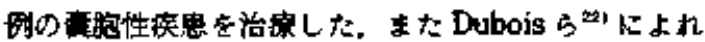

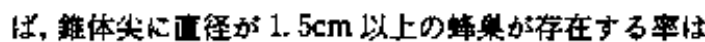

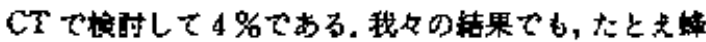

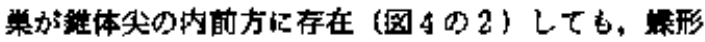

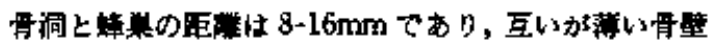

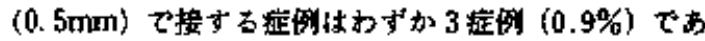

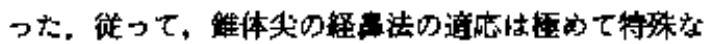
应例に限られる，本法の欠点は，以上の隄られた暗仙 例しか存在しないことに加えて，街野が限られること

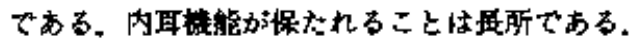

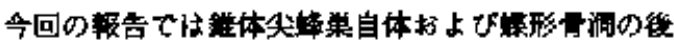

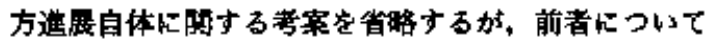

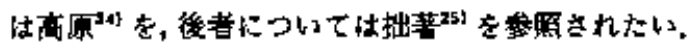

\section{IV 莎}

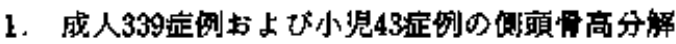

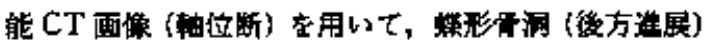

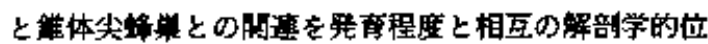
罒関保から分析した。

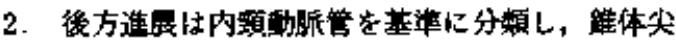

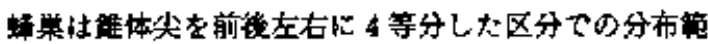
㽢虾占り分類した。

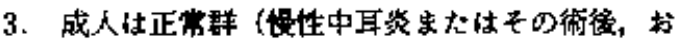

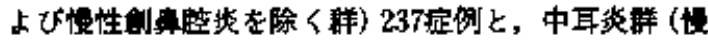

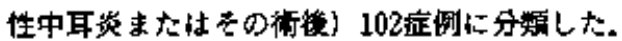

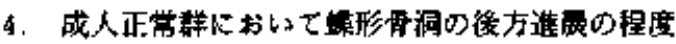

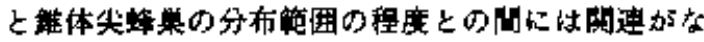
(1).

5、成人正常群を男子96症例，女子141症国的分けて 


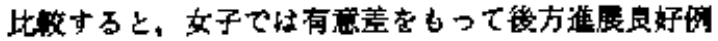

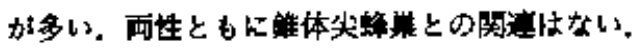

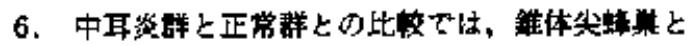

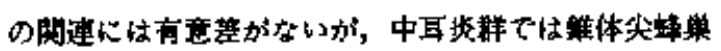

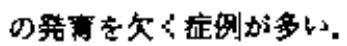

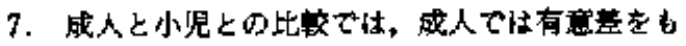

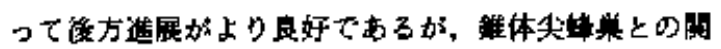
連には而者に䓔杜ない。

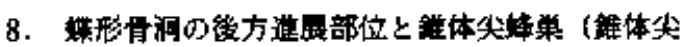

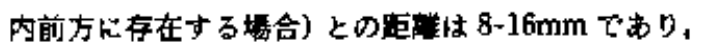

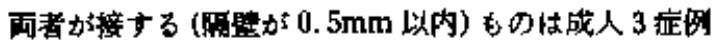
(0.9\%) でかった.

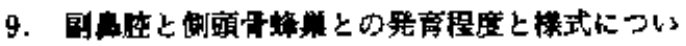

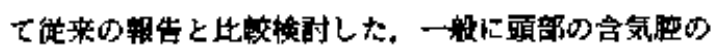

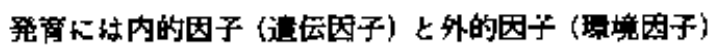

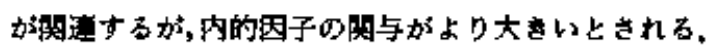

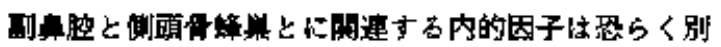
個であろる，ただし外的因子については内的因子ほど

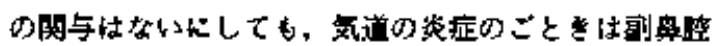

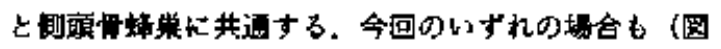
6.7.8，9) 後方僬层不良 $(1+$ II) 群て䤵体尖 蜂紫発育欠如群(A)が多くみられたことへの一つの解 夥たりるよう。

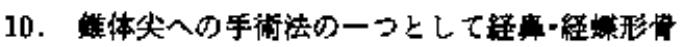

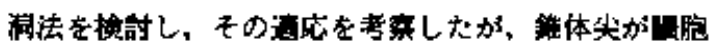

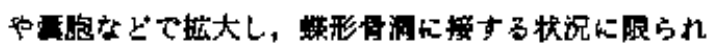
3 .

\section{女 酶}

1) Tobeck A : Antatomische Untersuchungen ueber die Preumatization von Felsenbein und die Wegleitung zur Spitze. Z f Hals-usw Heilk 37 : 152-164, 1934.

2) Schmidt D: Ueber die Pyramidenspitzen pneumatisation. Z f Hals-usw Heilk 41: 93-108. 1937.

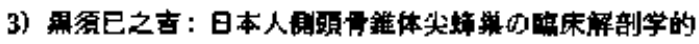

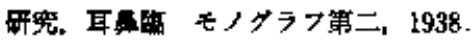

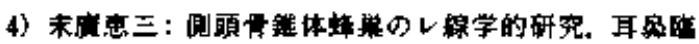
$38: 315-354,1943$.

5) Schuknecht HF and Gulya AJ : Anatomy of the Tomporal Bone with Surgical Implications Lea \& Febiger, Philadelphia, 1986. pp 111-124.

6) Turner L and Porter WG: The structural type of the mastoid process, based upon the skiagraphic examination of one thousand crania of various races of mankind. J Laryngol 37 : 161-175, 1922.

7) Beck J: Beziehungen zwischen der Pneumatisation des Warzenfortastzes und der Pneumatisation der Nasennebenhoehlen-eine vergleichende roentgenologische Studie. Z f Hais-tssw Heilk 18: 672$677,1927$.

8) Talpis L and Lieberman $G$ : Ueber Pneumatisienmg des Warzenforsatzes. Zentrbl $f$ HNO $11: 848$, 1928.

9) Schwar2 M : Die Bedeutung der bereditaeten Anlage fuer die Pneumatisation der Warzenfortsaetzen und der Nasennebenhoehlen. Arch $f$ Ohrenusw Heilk 123: 159-227, 1929.

10) Theissing $G$ : Roentgenologische Untersuchungen ueber die Struktur des Wartzenfortsatzes. $Z \mathrm{f}$ Hals-usw Heilk 25 : 137-156, 1930.

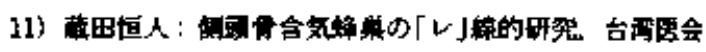

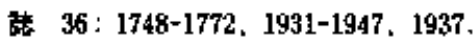

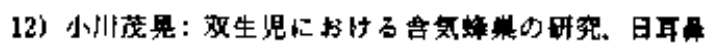
63 : 2000-2014, 1960 .

13) Leicher $\mathrm{H}$ : Die Vererbung anatomischen Var. fationen der Nase ihrer Nebenhoehlen und des Gehoerorgans. J F Bergmann, Muenchen, 1928, pp 127-128.

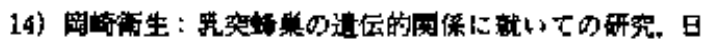
耳象 42 : 1653-1686, 1936.

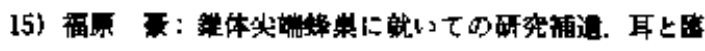
5(啋 4) : 145-163. 1959.

16) Meier E : Zur Fortleitung otitischer Eiterungen in die Schaedelhoelle durch den Canalis caroticus. Axch f Onrenheilk 38: 259-268, 1895.

17) Habermann J: Ueber Erkrankungen des Felsenbeins und des Ohrlabyrinth infolge der actien eitrigen Mittelohrenentzuendungen. Arch f Ohren. heilk $42 ; 128-173,1897$.

18) Mayer $O$ : Die Pyramidenzelleneiterungen $Z$ f Halsusw Heilk 42: 1-86, 1937.

19) Chole RA: Petrous apictitis: surglcal asatomy. Ann Otol Rhinol Laryngo: 94 : 251-257, 1985.

20) Cole TB and McCoy. G : Congenital cholesteatoma of the temporal bone and sphenoid sinus. Arch Otolaryngol 87 : 576-579, 1968 .

21) Montgomery WW: Cystic tesions of the petrous apex : transsphenoidal approact. Trans Am Otol Soc $65: 32-39,1977$.

22) Dubois PJ and Roub LW : Giant air cells of the petrous apex: tomographic features. Radiology 
129: 103-109. 1978.

23) Gacek RR : Diagnosis and management of primary tumors of the petrous apex. Ann Orol Rhinol Laryngol 84 : Supp 18, No. 1 Part 2, 1975.

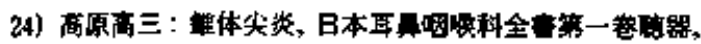

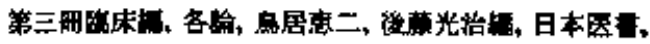
本京, 1953, pp 146-152.

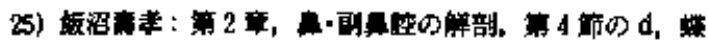

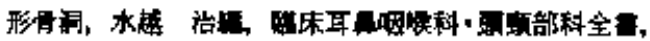

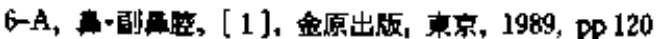
-132 .

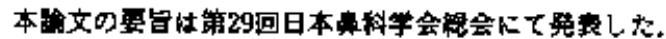

(1990年 8月21日受花 1990年10月18日受理)

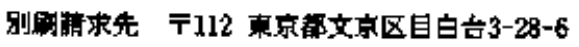

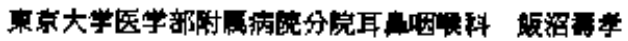

